\title{
Pedunculate Club-rush Bolboschoenus laticarpus (Cyperaceae) - an overlooked native or a spreading neophyte?
}

\author{
Frederick J. Rumsey*, Helena J. Crouch, Richard V. Lansdown, Mark A. Spencer
}

*Corresponding author: Frederick J. Rumsey, email: F.Rumsey@nhm.ac.uk

This pdf constitutes the Version of Record published on $21^{\text {st }}$ May 2019

\begin{abstract}
Bolboschoenus laticarpus Marhold, Hroudová, Zákravský \& Ducháček (for which we suggest the common name Pedunculate Club-rush) is reported from the British Isles and the characters which distinguish it from B. maritimus (L.) Palla are given. The known English distribution is presented and placed in its wider geographical context. The ecology and history of this species in Britain are outlined and its likely status is considered. $B$. laticarpus is locally abundant and widely distributed in a range of natural and artificial habitats, particularly within the Somerset Levels and also in the flood plains of some larger rivers, where it is now known to have been long persistent. $B$. laticarpus appears to be a successful colonist, having arrived recently in several newly created, artificial habitats. The mode of introduction is unknown but believed to be natural, and indeed elsewhere in Europe it is reportedly increasing within its natural range, perhaps as a consequence of changes in land-use, eutrophication and potentially climate. We therefore regard it as a native taxon.
\end{abstract}

Keywords: distribution; fruit anatomy; taxonomy; status; Somerset Levels

\section{Introduction}

The morphological variation demonstrated by British examples of the genus Bolboschoenus, particularly in the form of the inflorescence, and their taxonomic treatment, has long exercised and confounded British botanists. White (1912) neatly summed up the situation when he said "The inflorescence of this plant varies from an irregular compound umbel with some primary rays at least three inches long (umbellatus Reichb.), to a head or cluster of sessile spikes (compactus Koch $=$ conglobatus Gray), or even to the depauperate condition of a solitary spike (monostachys Sonder)... every connecting link can be traced through this remarkable series of variations, which are difficult to account for." Reliance on this extremely variable character alone resulted in failure to distinguish discrete and meaningful entities; only once ecology and fruit anatomy were considered in parallel with gross morphology were separate taxa recognised.

Modern monographic studies on the genus commenced with the work of Browning, who with her co-workers dealt in detail with South African taxa (Browning \& Gordon-Gray, 1993, 1999; Browning et al., 1998), North American taxa (Browning et al., 1995) and Australasian taxa (Browning et al., 1997a). During the course of this work, European (including British) material was examined in herbaria and a taxon new to Europe, B. yagara (Ohwi) Y. C. Yang \& M. H. Zhan, was reported 
(Browning et al., 1996, 1997b) along with its putative hybrid with B. maritimus. These publications appear to have been overlooked by British workers and it was not until the publication of the BSBI Cyperaceae handbook (Jermy et al., 2007) that specimens at $\mathbf{K}$ determined by Browning as this hybrid, from v.cc. $6,17 \& 21$, were brought to the attention of British botanists. The handbook authors, however, noted that "further work will be necessary to determine the precise status both of this material and of this taxon".

The anatomical characters of the fruit identified by Browning et al. (1993), the differences in fruit shape (Hroudová et al., 1998a) and architecture of the inflorescence (Hroudová et al., 1998b), correlated with eco-physiological features, gave additional credence to the recognition of a greater number of taxa within Bolboschoenus. Hroudová et al. (2007) produced a synthesis of their global studies which recognised five species in Europe, where previously DeFilipps (1980) had only recognised one species, with two subspecies. One of the five species, $B$. laticarpus Marhold, Hroudová, Zákravský \& Ducháček, which had recently been described by Marhold et al. (2004), equated to the material formerly considered by Browning to be the hybrid between $B$. maritimus and $B$. yagara. A possible hybrid origin of $B$. laticarpus involving these parents was also suggested by Marhold et al. (2004). Hroudová, however, had previously (Hroudová, 2002) considered that the parentage of $B$. laticarpus may be $B$. yagara $\times B$. koshewnikovii (Litv. ex Kots) A. E. Kozhevn. (= B. planiculmis (F. Schmidt) T. V. Egorova). Detailed molecular studies by Píšová et al. (2017) have demonstrated this to be the case: $B$. laticarpus is genetically and morphologically intermediate between $B$. yagara and $B$. planiculmis and is a stable hybridogenous species.

Preliminary DNA studies using the universal barcoding regions ( $\mathrm{RbCL}$ and Mat K) (Hollingsworth et al., 2011) revealed that four of the European taxa show no sequence variation between them: only $B$. yagara differed (Katy Jones, unpublished data). While it is disappointing that the barcoding markers cannot be used to discriminate vegetative material of $B$. laticarpus from $B$. maritimus, this result supports the recognition of $B$. laticarpus as distinct from $B$. yagara. Furthermore, it suggests that $B$. yagara must have been the paternal parent in the initial cross.

Few British specimens of Bolboschoenus were seen by Hroudová and colleagues and only B. maritimus was listed in Hroudová et al. (2007) as British. Yet even prior to the publication of the BSBI handbook in 2007, several field botanists had struggled to reconcile the plants that they were finding with their accepted concept of $B$. maritimus. The long-pedunculate inflorescences give a habit reminiscent of Cyperus longus L., noted over a century ago by Syme (1870). Such plants had been brought to the attention of MAS by Leslie Williams from Brent Council, Greater London, while as early as 2004 Belinda Wheeler had expressed similar doubts to Ian Bennallick about the identity of plants she had found at Porth Reservoir, Newquay. The final catalyst to the eventual recognition of $B$. laticarpus as a British species was the discovery of large populations of the plant in August 2010, by RVL and Nick Monaco, during surveys for the Environment Agency supporting the Thames Flood alleviation project. RVL was confident that the plant was not $B$.

maritimus and following a search of European literature, he and FJR examined and determined the specimens as $B$. laticarpus, subsequently confirmed when this and other material from BM was sent to Zdenka Hroudová. Following the report of this find and the key diagnostic features at the BSBI exhibition meeting later in 2010, material from a range of British and Irish sites has been submitted to the authors for 
determination. Several major British herbaria have been searched for historical material to establish both the species distribution and its history within Britain. Fieldwork has targeted inland sites for "B. maritimus" reported in the literature. From the results of herbarium studies and fieldwork, an informed consideration of the status of this species within Britain has been made.

\section{Description}

Stout glabrous perennial, with deciduous shoots, from a branched underground rhizome bearing elliptical to spherical tubers, to $3 \mathrm{~cm}$ diameter. Leaves basal and cauline, to $c .10 \mathrm{~mm}$ wide. Flowering stems erect, trigonous, to $1.5 \mathrm{~m}$ tall, with distinct patches of aerenchyma between the vascular bundles in cross-section. Inflorescence terminal, branched consisting of a central group of 2-7(13) clustered sessile spikelets and of (2)4-7 peduncles bearing fascicles of (1)2-4(8) spikelets, peduncles (5)10-35(55) mm long. Sessile spikelets (6)10-16(21) mm long, pedunculate spikelets (4)8-16(21) mm long. Glumes light to rust-brown, 5-7 × 2.5$3.2 \mathrm{~mm}$. Flowers bisexual; perianth bristles (0)3-6, unequal, retrorsely scabrid, usually partly persistent in fruit; stamens 3, stigmas (2)3. Achene (nut) 3.1-3.7 $\times$ 2.0-2.4 mm, obovate, trigonous (often obtusely so) with low sharp to nearly rounded edge on abaxial face, rarely plano-convex on flowers with bifid styles, darkbrown to blackish at maturity. Pericarp with a thin exocarp of isodiametric to slightly taller than wide, air-filled cells, less than half the width of the thicker sclerenchymatic mesocarp (Fig. 1).

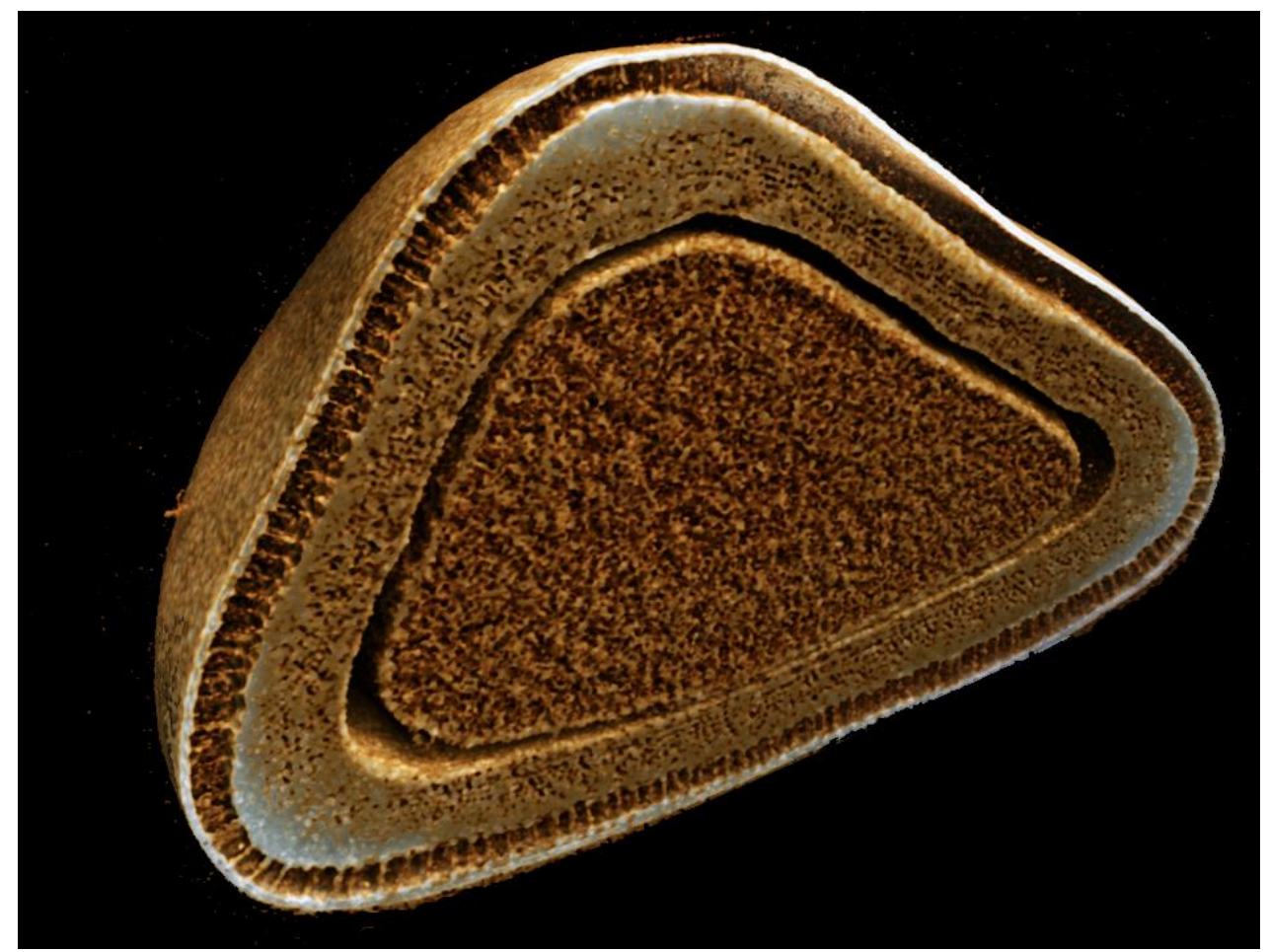

Figure 1. Transverse section of Bolboschoenus laticarpus achene (NHM).

\section{Key to British species (see also Fig. 2)}

Inflorescences all with (2-)4-7 long peduncles, the longest c. $2 \times$ the length of the sessile spikelets; achenes with +/- persistent perianth bristles, outer layer of the pericarp (exocarp) thinner than the mesocarp B. laticarpus 
Inflorescence of sessile spikelets, sometimes shortly pedunculate, peduncles $<2 \times$ the length of the sessile spikelets; achenes with +/- caducous perianth bristles, outer layer of the pericarp (exocarp) much thicker than the mesocarp B. maritimus

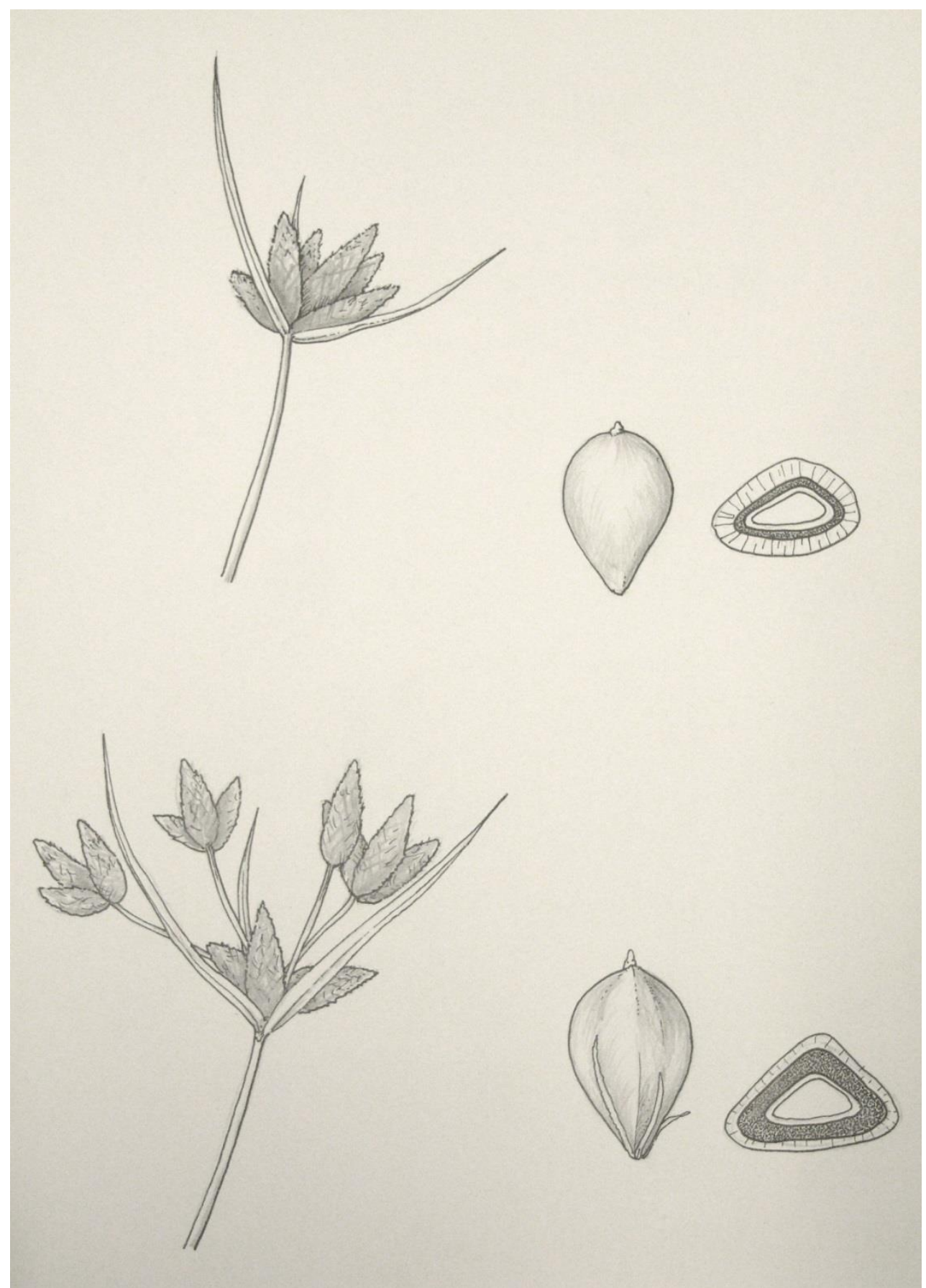

Figure 2. Typical inflorescence form and achene characters: $B$. maritimus above, B. laticarpus below.

It should be stressed that the peduncle character alone is not always reliable as individuals in some populations of $B$. maritimus have peduncles which may exceed 2 $x$ the length of the sessile spikelets (Fig. 3). Typically these show more sessile spikelets than those borne on peduncles (in contrast to B. laticarpus, cf. Fig. 4) but confirmation must always be sought from the achene characters. Even in young developing achenes the proportions of the exocarp to mesocarp are still diagnostic. 


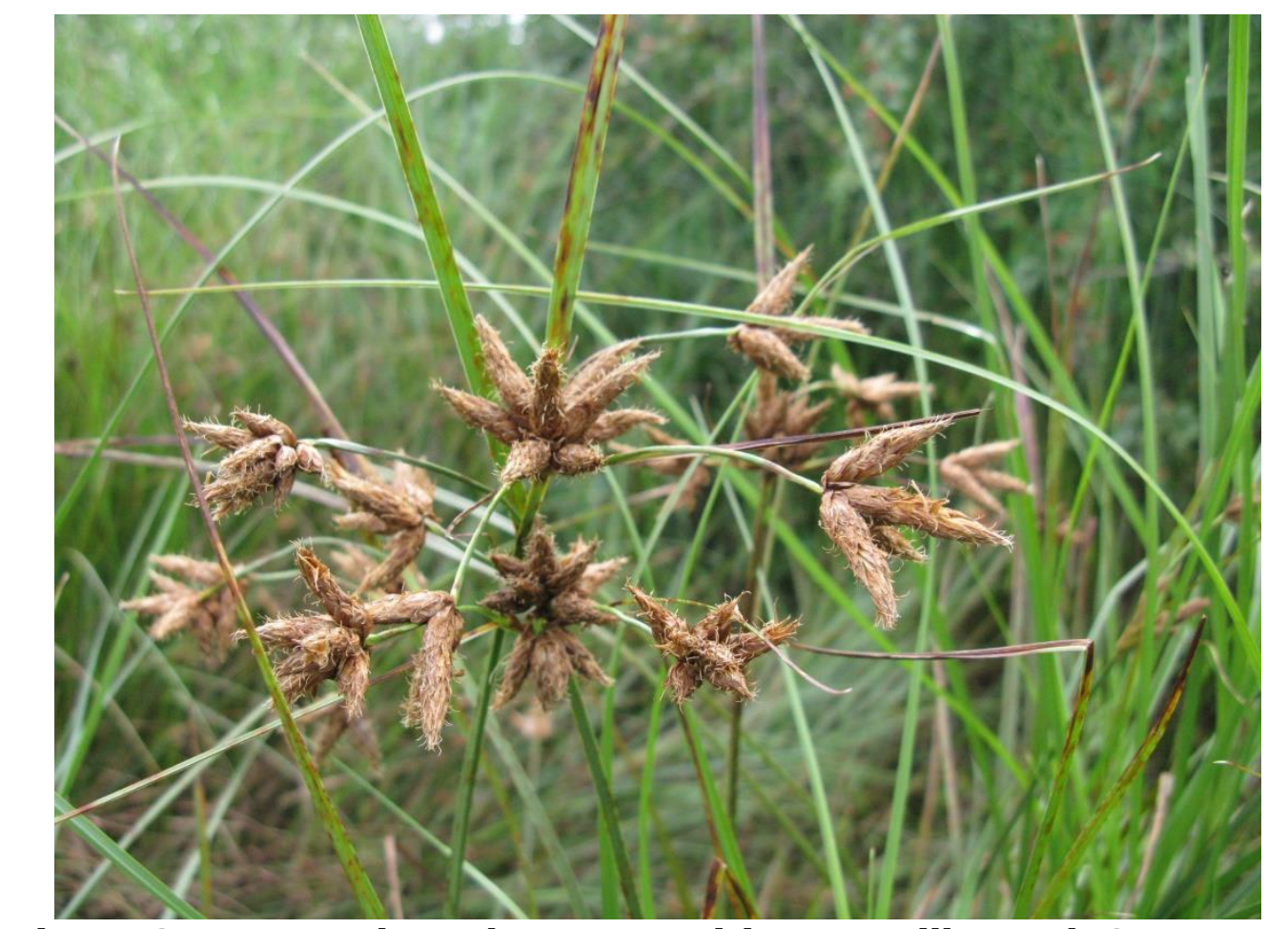

Figure 3. Long-pedunculate B. maritimus at Pill, North Somerset.

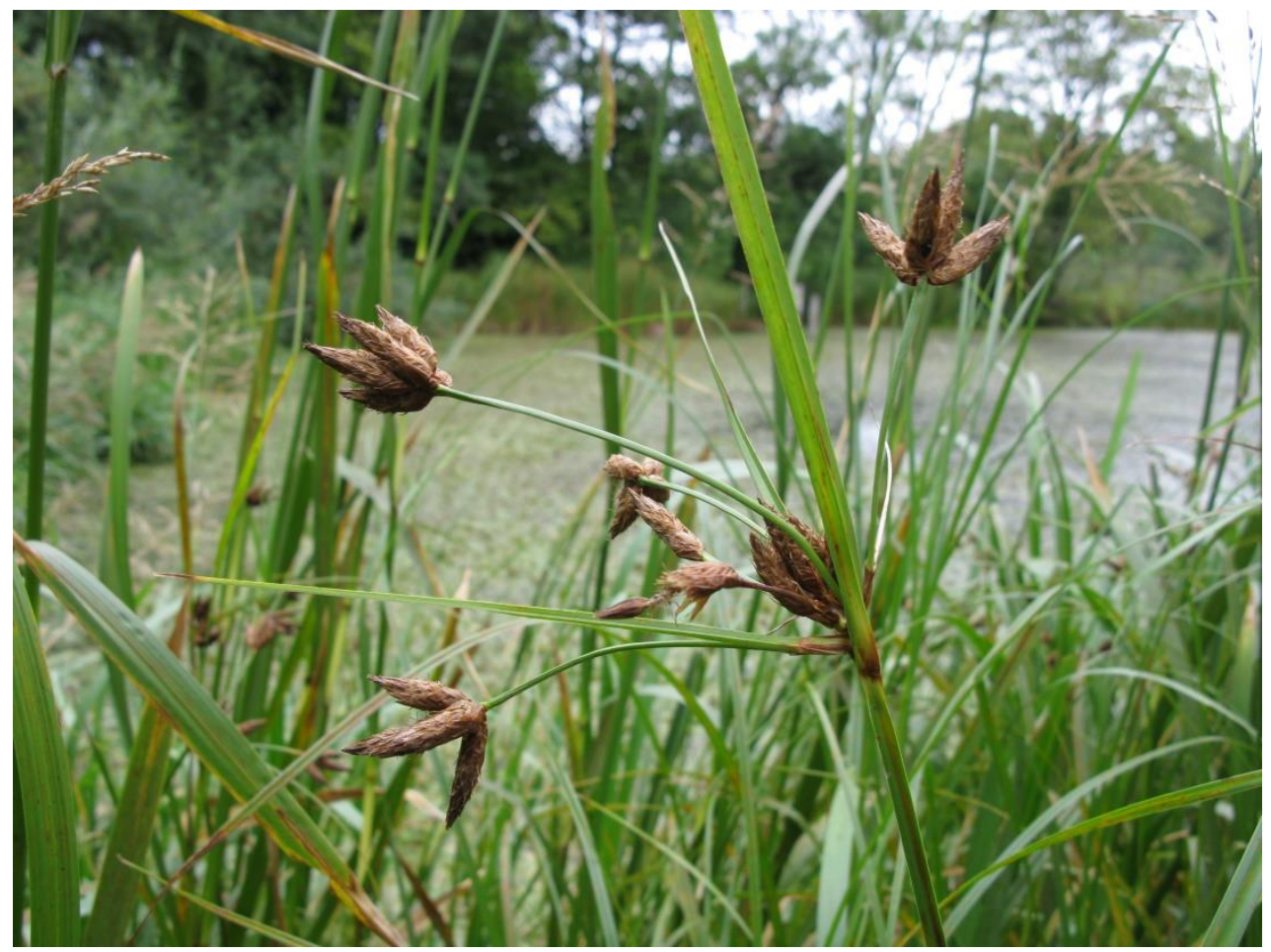

Figure 4. B. laticarpus at Preston Montford, Shropshire.

The possible presence of $B$. yagara in Britain and Ireland should not be dismissed: this species is found as close as N. Central France near Paris and also in S. Sweden (Hroudová et al., 2007). It differs from B. laticarpus in the narrower achenes, $1.6-1.8 \mathrm{~mm}$ wide (cf. 2.0-2.4 $\mathrm{mm}$ in B. laticarpus), more sharply equilaterally triangular in cross section, the perianth bristles proportionately longer, almost equalling the achene (cf. about $2 / 3$ rds the length) and the very thin exocarp of isodiametric cells ( $c f$. cells taller than wide). It is consistently long-pedunculate 
and usually has 3 stigmas ( $c f$. some spikelets with 2). It might be sought in similar but perhaps more oligotrophic habitats.

\section{World distribution}

The distribution of Bolboschoenus laticarpus is still somewhat unclear as the species was only recognised in 2004 (Marhold et al., 2004). It would seem to be frequent and particularly abundant in central Europe, where it occurs especially along the larger rivers, eg. the Main, Elbe, Morava, Odra, Tisza, Danube, in lowland floodplains (Hroudová et al., 2007). It is apparently rarer in southern Europe but still frequent in parts of Bulgaria, Romania, Serbia and Northern Italy. B. laticarpus extends more patchily westwards through France, reaching its westernmost limits in the British localities listed below. To the north it occurs rarely on the islands in the Baltic Sea, in Estonia and Russia; eastwards it extends continuously to the Urals, then with disjunctions in the far east of the former USSR (Tatanov, 2004). Plants from Japan (Honshu \& Kyushu) identified as B. fluviatilis subsp. yagara type "B" by Hayasaka \& Ohashi (2002) also appear to be B. laticarpus.

\section{Habitat and distribution in Britain}

Consideration of all of the confirmed British records for B. laticarpus (see Fig. 5 and Appendix), as opposed to B. maritimus agg. (Fig. 6), leads to the recognition of six, somewhat overlapping, broad habitat/feature types for the former:

- In and by major rivers, in natural features on floodplains and in later gravel extractions in these areas

- Rhynes and drainage ditches on the Somerset Levels

- Meres and kettleholes

- farm ponds and other small standing water bodies away from rivers

- ornamental lakes associated with stately homes

- recent artificial reservoirs (although $B$. maritimus can occur beside inland reservoirs: see below)

These range from natural and relatively ancient features, to artificial and very recent ones; it is of course, the means by which these habitats have been colonised which determines the accepted status (see below).

A claim of native status for this species is perhaps best supported by its presence as a component of particular riverine systems. The earliest literature record which we can place with some conviction is that of Pulteney (1799) from the R. Stour at Durweston, just NW of Blandford Forum (where he was living in 1790). One of the earliest herbarium specimens yet traced, Mansell's dating from 1863, is also from beside the Stour. The locality is not easily decipherable beyond the first three letters but almost certainly is the site "opposite Bryanstone House" mentioned in his Flora of Dorset (Mansell-Pleydell, 1895). Pearman (1994), describing Bolboschoenus in Dorset, says "In salt and brackish marshes and ditches. Occasionally in freshwater habitats for reasons that are not clear." The majority of the plants which perplexed him were those "...ten or more recent records from the upper River Stour, from Stalbridge southwards, more than 25 miles from the sea." These, we contend are very likely to be $B$. laticarpus and much of the mystery surrounding the apparent ecological dichotomy demonstrated by $B$. maritimus is therefore solved. Indeed, in 2016 unequivocal specimens of $B$. laticarpus were found in Dorset by FJR and HJC beside the R. Cale, which is a tributary of the Stour. Historically the species had been recorded further down the Stour (see Fig. 7), but 
in spite of recent searches it has proved elusive, although perhaps overlooked as flowering has been unreliable.

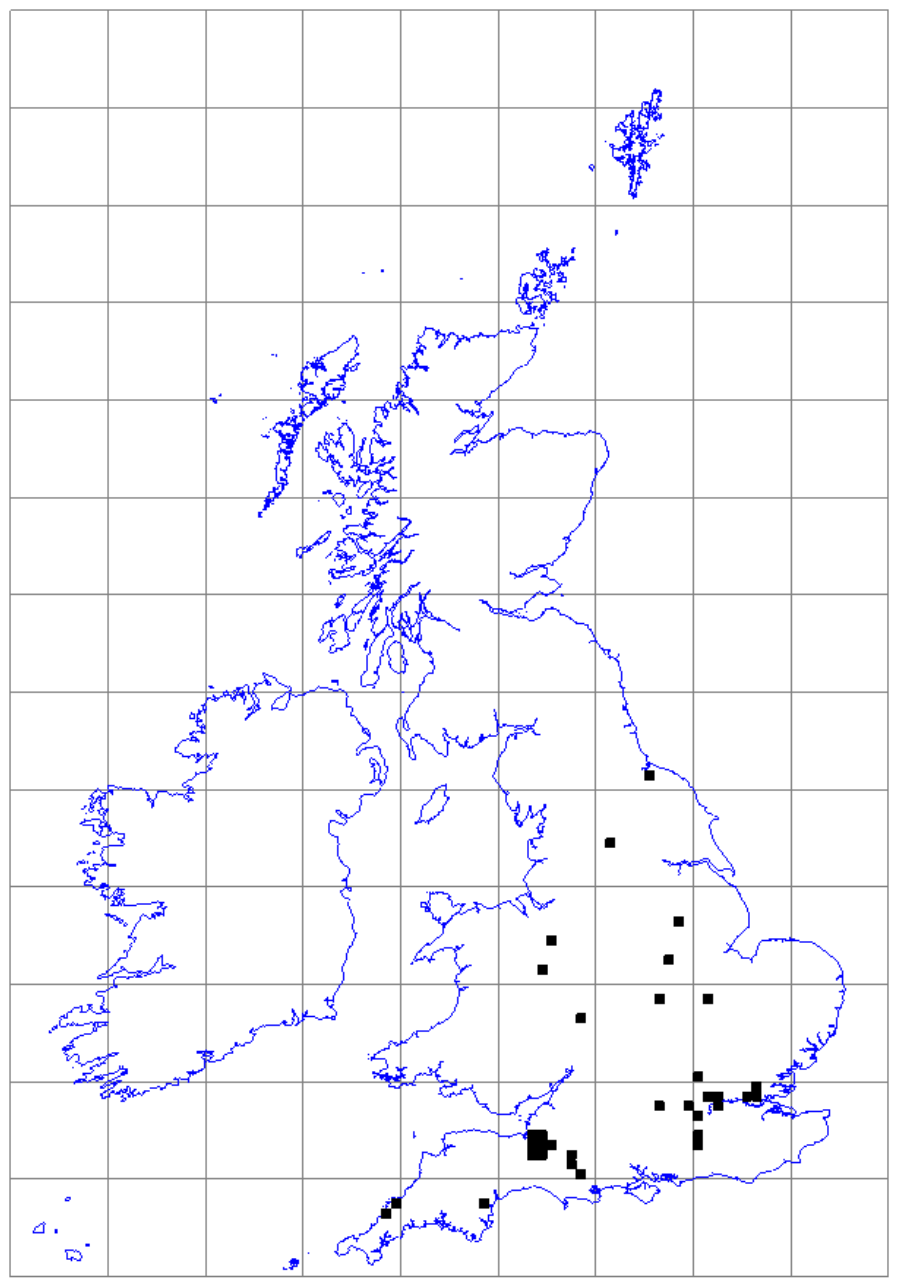

Figure 5. Distribution of Bolboschoenus laticarpus in Britain: all recent and historic records confirmed or accepted by the authors, December 2018 (mapped using MapMate)

The close and long-established association with the R. Stour and tributaries is clear; scattered occurrences close to major rivers elsewhere are also suggestive of native status. Ponds on the floodplain of the River Severn at Holt Castle, v.c.37 Worcestershire, support the plant in a natural setting. More difficult to assess are those situations where the plant is present in more recent man-made features closely adjacent to what may have been natural habitat. The gravel winnings which have given rise to the Thorpe Park lake complex lie immediately adjacent to the $R$. Thames. Extensive survey by RVL in 2012 and 2013 revealed the species to be present along the eastern margin of Abbey Lake, by Fleet Lake, on recently created habitat at Manor Lake and beside two other lakes in the complex. Elsewhere, by the R. Wharfe, the gravel pits at Ben Rhydding (home to another Cyperaceous floodplain specialist, Eleocharis mamillata $(\mathrm{H}$. Lindb.) $\mathrm{H}$. Lindb.) also support B. laticarpus along with a range of ruderal neophytic taxa. 


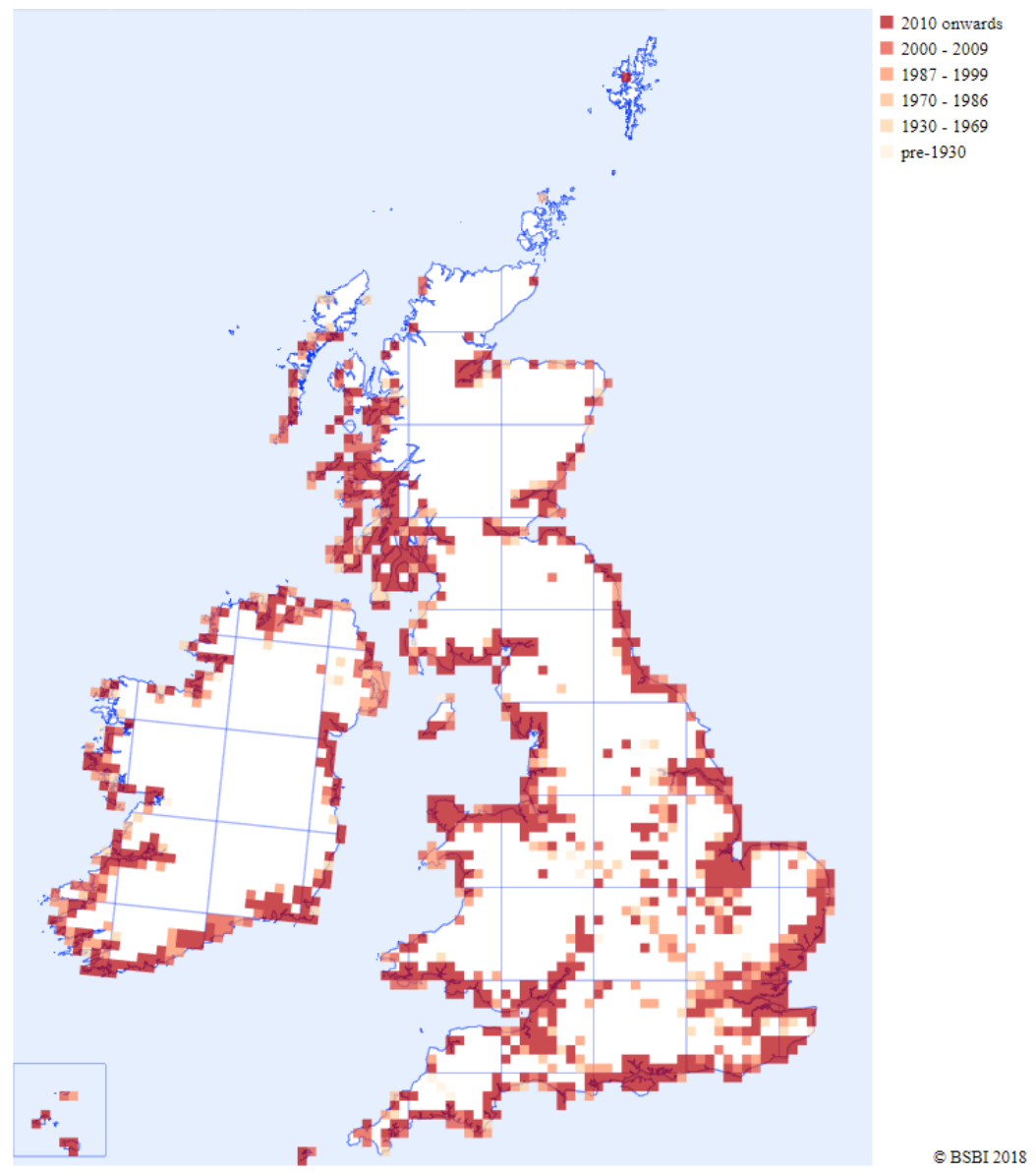

Figure 6. Distribution of $B$. maritimus agg. in Britain and Ireland (records in the BSBI Distribution Database, December 2018)

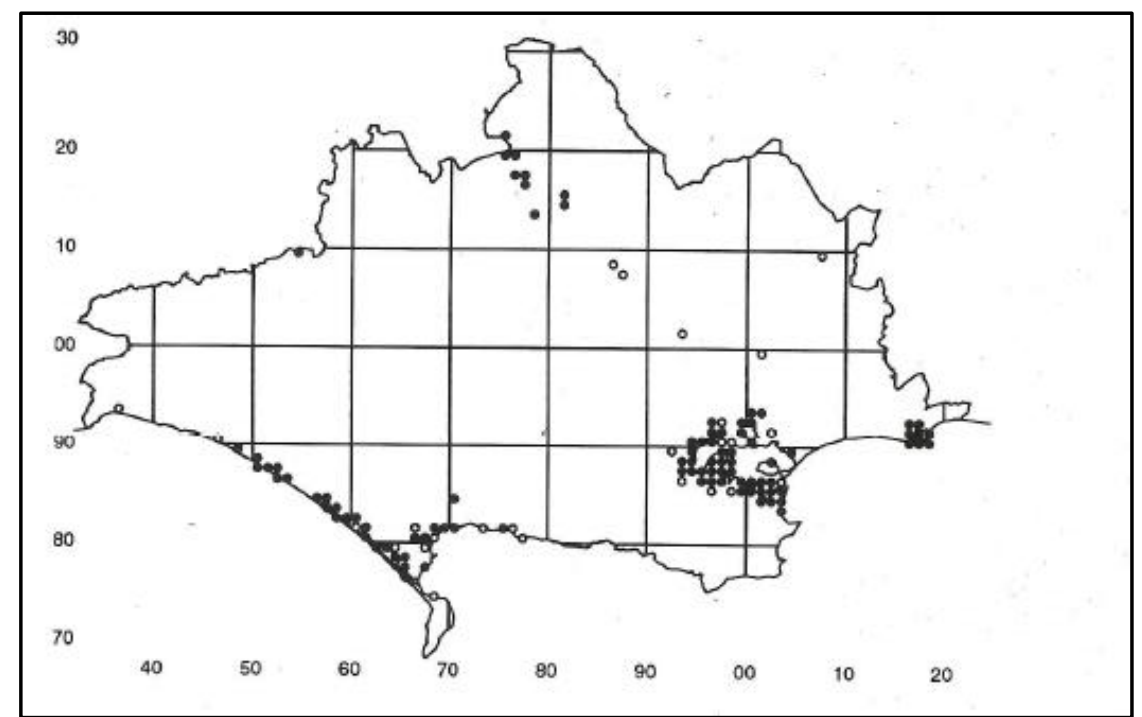

Figure 7. Distribution of the genus Bolboschoenus in Dorset (v.c. 9) (reproduced from Pearman (1994) with permission).

In Britain, the Somerset Levels are now the undoubted hot-spot for this species. Prior to drainage of the Levels in the $17^{\text {th }}$ and $18^{\text {th }}$ centuries the area would have been brackish to some extent and thus potentially unsuitable for $B$. laticarpus. The creation of the extensive series of rhynes, dykes and ditches would have provided extensive areas of suitable freshwater habitat for this species to colonise. 
By the late $19^{\text {th }}$ century, Murray (1896) noted that Scirpus maritimus L. was occasionally found inland by rivers. He listed a number of sites away from the influence of the sea: "Middlezoy ... ditches by Walton Drove, and between Ilchester and Long Load, at a distance of twenty miles from the sea ... By the Cale in two or three places ... this station must be quite thirty miles from the sea". A specimen in BM collected by Murray in 1891 from a ditch near Long Load has been determined as $B$. laticarpus. Two earlier specimens collected by T. Clark: "Turf Moor, Somerset" 30/7/1855 (BIRM 012580) and "Reen by the road side between Highbridge and Burnham" 21/7/1835 (BIRM 012603), viewed on Herbaria@Home, appear to be $B$. laticarpus. If confirmed these would represent the earliest British gatherings yet identified.

On the Somerset Levels, all flowering plants checked in recent years have proved to be $B$. laticarpus, as have plants found recently by the River Cale, although only on the Dorset bank of the river. It is thus likely that all the inland records listed by Murray (1896) were in fact $B$. laticarpus. White (1912) recognised variation in the umbels of Scirpus maritimus, stating that plants with "an irregular compound umbel with some primary rays at least three inches long" were found in peaty ditches far from the sea, whilst plants with "a head or cluster of sessile spikes" or "a solitary spike" occurred on saltmarshes on the coast. This recognition of the occurrence of separate taxa in ecologically distinct sites appears to have been overlooked in subsequent floras, perhaps because White stated that inland sites were formerly brackish, suggesting that where $B$. maritimus grew inland it was as a relic of a distribution formerly influenced by the sea. Subsequently all inland Bolboschoenus on the Somerset Levels has been recorded and mapped as B. maritimus until recently, mostly because this was the only species included in identification books or on recording cards. Although it seems incredible that a separate species could be overlooked over such a large area, Bolboschoenus on the Levels often forms large swathes of non-flowering plants and can be recorded in a vegetative state (as a genus) for much of the year. Poor flowering of Bolboschoenus plants inland has made it difficult to establish the exact distribution of $B$. laticarpus.

As yet there are few records from the meres of the Cheshire, Staffordshire and Shropshire plain, "the least well-known lake district in Britain and Ireland" (Moss, 2015). Currently recorded from Oss Mere and at Preston Montford in v.c. 40 Shropshire and from Marbury Mere in v.c. 58 Cheshire, we anticipate it will be found to occur more widely. If so, its presence as a regular component in these natural peri-glacial features would strengthen the argument for its native status.

Many records are from ponds and small water bodies not obviously associated with rivers, such as those at Shenfield and Cranham in Essex, (see Appendix) and likely to be of more recent origin. Several occur close to farmsteads, or on commons and village greens. The status of the plant in these sites, many of which are artificial, used for livestock, or have been subject to planting of other aquatic species and are distant from natural sources, is less clear-cut. Likewise there are several occurrences associated with ornamental lakes in the landscaped grounds of grand houses and public schools, from near Harrow (Northwick Park) to the regal environs of Buckingham Palace. Such aquatic features will have been created, or at least very significantly modified, in the $18^{\text {th }}$ or $19^{\text {th }}$ centuries and plantings of marginal plants may have been made at those times.

Bolboschoenus laticarpus is also present around open reservoirs, mostly created in the latter part of the $20^{\text {th }}$ century, from Porth (v.c. 1 West Cornwall) to 
Brent (v.c. 21 Middlesex). It is unsafe to assume, however, that any Bolboschoenus found on the shore of a reservoir is this species, since plants growing at the edge of Blagdon Lake in the Chew Valley (v.c. 6 North Somerset), a freshwater reservoir about $18 \mathrm{~km}$ from the sea, opened in 1905, have been confirmed to be $B$.

maritimus. Indeed herbarium specimens indicate that $B$. maritimus first colonised the shore of Blagdon Lake soon after its creation. It is probable that visiting wildfowl have been the means of dispersal of both species to these sites, and possibly to the other sites discussed previously. It would seem that several of the earlier inland records were of colonists that did not persist. This may be a feature of the species and its possible lack of seed bank (see Hroudová et al., 1997), but it should also be noted that at many of its rather isolated inland pools and lakes it has proved persistent over more than 50 years. Thus, for instance, the plant has been known but not recognised at Preston Montford, v.c. 40 Shropshire, since 1957.

Bolboschoenus laticarpus has to date only been found in freshwater situations, being apparently entirely replaced by $B$. maritimus in brackish conditions. The former is therefore essentially inland and non-coastal, whereas the latter is largely, although not exclusively, coastal in its distribution. Some inland occurrences of $B$. maritimus can be explained through the presence of saline deposits, for example at Defford Common, v.c. 37 Worcestershire (Chatters, 2017) and the now apparently lost population from Marcham, v.C. 22 Berkshire. Herbarium specimens at BM! show this latter population to be extremely variable in inflorescence form, as noted by Druce (1897); however, even the most pedunculated specimens have the fruit characters of $B$. maritimus and there is no evidence of hybridity.

It was the authors' initial expectation that all inland freshwater occurrences of Bolboschoenus might prove to be $B$. laticarpus, however, populations on the shore of Blagdon Lake, (v.c. 6 North Somerset) ST56 proved to be B. maritimus (see above), as did fruiting material collected by George Hounsome from Tiddenfoot Lake, v.c. 24 Buckinghamshire (SP91512391) in 2012, a site from which Bolboschoenus was first reported in 1973 (Boon \& Outen, 2011). This species demonstrates a wider ecological tolerance over a greater range of water chemistries and hydrological conditions than $B$. laticarpus. The first recorded dates of " $B$. maritimus" in many inland vice-counties are comparatively recent, eg. v.c. 30 Bedfordshire, 1945 (Boon \& Outen, 2011), v.c. 20 Hertfordshire, 1958 (James, 2009), v.c. 7 Wiltshire, 1987 (Gillam, 1993) and v.c. 32 Northamptonshire, 1997 (Gent \& Wilson, 2012): none of these has been examined by the authors, but our expectation is that some, at least, will prove to be $B$. laticarpus.

\section{British status of B. laticarpus}

Specimens of Bolboschoenus in several major UK herbaria have been examined: so far the oldest confirmed British specimen of $B$. laticarpus is from as recently as 1863, although plausible but as yet unchecked material from 1855 and 1835 exists. One would have expected that this species, which clearly lies at one striking extreme of the morphological spectrum previously associated with $B$. maritimus, would have been targeted by collectors had it been present earlier. It is possible that further work in other herbaria will reveal earlier vouchers and the mention in Pulteney (1799) suggests a longer history for this species in England.

The lack of early historical collections suggests that the species may be a relatively recent arrival, although it is of course the mode of arrival that signifies native status, i.e. natural dispersal from an area where the species might be 
considered native, as opposed to neophytic status, i.e. introduction by man (Preston, 2002).

Many of the recorded localities are artificial water bodies of comparatively recent origin. Without evidence that Bolboschoenus was deliberately introduced to these sites, it is suggested that anglers or wildfowl are the responsible vectors of introduction here. Bolboschoenus plants are, however, commercially available from a small number of specialist nurseries, often still sold as Scirpus maritimus. The specific identity of these plants and their geographic origins remain to be established: at least one UK commercial seed supplier sources material of "Bolboschoenus maritimus" from Serbia (Steve Morton, pers. comm.). Some at least may prove to be $B$. laticarpus. Dispersal of non-native material from private gardens, or deliberate plantings of misidentified material for habitat creation/restoration or amenity wildlife schemes is thus theoretically possible.

In support of a native status, indications are that elsewhere in its continental range the species is increasing in abundance and colonising a wider range of habitats, even becoming somewhat invasive in neglected arable fields (Hroudová et al., 2007). We may be experiencing a similar expansion here, whether from relict populations in natural riverine flood-plain habitats, or from continental sources. The extent to which the scattered occurrences on or by other major lowland British rivers (for example the Thames, the Severn, the Trent, or even the Wharfe) might reflect the vestiges of past distribution, as opposed to recent colonisation, needs further research.

\section{Conclusions}

With hindsight the distinctness of this species is clear but the reasons for its being overlooked until now are equally obvious: we anticipate that this species will henceforth be more widely reported. Bolboschoenus laticarpus is apparently locally abundant and widely distributed in a range of (semi-)natural habitats, particularly within the Somerset Levels and in the flood plains of some major rivers, where it has been present for over 200 years. While behaving as a short-lived colonist in some artificial sites, in many it has persisted for over a century. B. laticarpus appears to be a natural colonist, capable of dispersal along watercourses by seed and vegetative means, but probably more widely dispersed to isolated water bodies by wildfowl and perhaps unwittingly by anglers or other recreational users.

We have found no evidence that this species has been planted or intentionally introduced in any of the known locations and accordingly view it as a natural colonist. On balance we therefore regard Bolboschoenus laticarpus as a native taxon, not a neophyte.

The discovery of unequivocal $B$. maritimus in inland situations has a bearing on how we deal with historical records from inland sites. In the absence of a fruiting voucher specimen it is not possible to assign these records to anything other than an aggregate, for which we would suggest using Bolboschoenus maritimus agg. to avoid spurious and misleading records.

\section{Acknowledgements}

We thank Zdenka Hroudová for confirming the identity of specimens and providing material of all of the European taxa for anatomical and molecular investigation. We also thank Michael Wilcox for his sustained interest and help with determinations of specimens, Katy Jones for performing preliminary DNA studies and the Cothill 
Education Trust which, under the Decoding NAture project, supported the molecular work. We thank Farah Ahmed (NHM) for preparing the SEM used for Fig. 1. We also wish to thank Robin Walls for information on his collections and on specimens at DOR, Andrew Branson and David Pearman for additional advice and records relating to Dorset, and the many herbarium curators, Vice-county recorders and other BSBI members who have kindly allowed us access to their material and records.

\section{References}

Boon, C.R. \& Outen, A. 2011. Flora of Bedfordshire. Bedfordshire Natural History Society.

Browning, J. \& Gordon-Gray, K.D. 1993. Studies in Cyperaceae in southern Africa. 21. The taxonomic significance of the achene and its embryo in Bolboschoenus. South African Journal of Botany 59: 311-318.

Browning, J. \& Gordon-Gray, K.D. 1999. The inflorescence in southern African species of Bolboschoenus (Cyperaceae). Annales Botanici Fennici 36: 81-97.

Browning, J., Gordon-Gray, K.D. \& Smith, S.G. 1995. Achene structure and taxonomy of North American Bolboschoenus (Cyperaceae). Brittonia 47: 433445.

Browning, J., Gordon-Gray, K.D. \& Smith, S.G. 1997a. Achene morphology and pericarp anatomy of the type specimens of the Australian and New Zealand species of Bolboschoenus (Cyperaceae). Australian Systematic Botany 10: 4958.

Browning, J., Gordon-Gray, K.D., Smith, S.G. \& van Staden, J. 1996. Bolboschoenus yagara (Cyperaceae) newly reported for Europe. Annales Botanici Fennici 33: 129-136.

Browning, J., Gordon-Gray, K.D., Smith, S.G. \& van Staden, J. 1997b.

Bolboschoenus maritimus s.l. in the Netherlands: a study of pericarp anatomy based on the work of Irene Robertus-Koster. Annales Botanici Fennici 34: $115-126$.

Browning, J., Gordon-Gray, K.D., Smith, S.G. \& van Staden, J. 1998. Bolboschoenus glaucus (Cyperaceae) with emphasis upon Africa. Nordic Journal of Botany 18: 475-482.

Chatters, C. (2017). Saltmarsh. London: Bloomsbury.

DeFilipps, R.A. 1980. Scirpus L. in Tutin, T.G., Heywood, V.H., Burges, N.A., Moore, D.M., Valentine, D.H., Walters, S.M. \& Webb, D.A. (eds.), Flora Europaea 5: 277-280. Cambridge: Cambridge University Press.

Druce, G.C. 1897. The flora of Berkshire. Oxford: Clarendon Press.

Gent, G. \& Wilson, R. 2012. The flora of Northamptonshire \& the Soke of Peterborough. Rothwell: Robert Wilson Designs.

Gillam, B. (ed.) 1993. The Wiltshire flora. Newbury: Pisces Publications.

Hayasaka, E. \& Ohashi, H. 2002. Achene gross morphology and pericarp anatomy of Japanese Bolboschoenus (Cyperaceae). Journal of Japanese Botany 77: 9-23.

Hollingsworth, P.M., Graham, S.W. \& Little, D.P. 2011. Choosing and using a plant DNA barcode. PLOS ONE 6(5): e19254. [Accessed 14 Dec 2018]. Available at: $<$ https://doi.org/10.1371/journal.pone.0019254>.

Hroudová, Z. 2002. 2. Bolboschoenus Palla - kamyšník. In Kubát, K., Hrouda, L. Chrtek, J., Kaplan, Z., Kirschner, J. \& Štěpánek, J., eds. Klić ke květeně České republiky, 794-795. Praha: Academia. 
Hroudová, Z., Ducháček, M., Zákravský, P. \& Marhold, K. 2007. Taxonomy, distribution and ecology of Bolboschoenus in Europe. Annales Botanici Fennici 44: 81-102.

Hroudová, Z., Frantík, T.\& Zákravský, P. 1998a. The differentiation of subspecies in Bolboschoenus maritimus based on the inflorescence structure. Preslia 70: 135-154.

Hroudová, Z., Moravcová, L. \& Zákravský, P. 1997. Effect of anatomical structure on buoyancy of achenes of two subspecies of Bolboschoenus maritimus. Folia Geobotanica Phytotaxonomica 32: 377-390.

Hroudová, Z., Moravcová, L. \& Zákravský, P. 1998b. Differentiation of central European Bolboschoenus taxa based on fruit shape and anatomy. Thaiszia Journal of Botany 8: 91-109.

James, T.J. 2009. Flora of Hertfordshire. Welwyn Garden City: Hertfordshire Natural History Society.

Jermy, A.C., Simpson, D.A., Foley, M.J.Y. \& Porter, M.S. 2007. Sedges of the British Isles - BSBI Handbook No $1,3^{\text {rd }}$ ed. London: Botanical Society of the British Isles.

Mansell-Pleydell, J.C. 1895. The flora of Dorsetshire, $2^{\text {nd }}$ ed. Dorchester: Dorset County Chronicle.

Marhold, K., Hroudová, Z., Ducháček, M. \& Zákravský, P. 2004. The Bolboschoenus maritimus group (Cyperaceae) in Central Europe, including B. laticarpus, spec. nova. Phyton 44: 1-21.

Moss, B. 2015. Lakes, loughs and lochs. London: Harper Collins.

Murray, R.P. 1896. Flora of Somerset. Taunton: Barnicott \& Pearce.

Pearman, D.A. 1994. Sedges and their allies in Dorset. Dorchester: Dorset Environmental Records Centre.

Píšová, S., Hroudová, Z., Chumová, Z. \& Fér, T. 2017. Ecological hybrid speciation in central-European species of Bolboschoenus: genetic and morphological evaluation. Preslia 89: 17-39.

Preston, C.D. 2002. Approaches to native and alien species. Suffolk Natural History 38: $37-48$.

Pulteney, R. 1799. Catalogues of the birds, shells, and some of the more rare plants, of Dorsetshire from the new and enlarged edition of Mr. Hutchins's history of that county. London, J. Nichols.

Syme, J.T.B. (ed.) 1870. English botany. Vol. X. Juncaceae to Cyperaceae, $3^{\text {rd }}$ ed. London: Robert Hardwicke.

Tatanov, I.V. 2004. The comparative carpology of Bolboschoenus species (Cyperaceae) in the context of the genus taxonomy. Botanicheskii Zhurnal SSSR. 89: 1225-1248.

White, J.W. 1912. The flora of Bristol, Bristol: John Wright and Sons.

\section{Appendix}

Specimens and fresh material identified as $B$. laticarpus by the authors and others:

v.c. 1 Porth Reservoir, Newquay, SW871620, B. Wheeler, 10/2004.

v.c. 1 Porth Reservoir, Newquay, SW86876199, SW87136207, SW87186208, I. Bennallick, 31/08/2011. (Det. M.P. Wilcox)

v.c. 2 Rooke Farm, $\mathrm{S}$ of, in stream/by pool at entrance to farm, SW995761, I.J. Bennalick \& D.A. Pearman, 23/04/2017. 
V.c. 2 Trevathan, S of, in damp field/by pond, SW995770, I.J. Bennalick \& D.A. Pearman, 23/04/2017.

v.c. 3 Little Bradley Ponds, near Bovey Tracey, SX829778, S. Wynn, 26/07/2011.

V.C. 5 ditch near Long Load, R.P. M[urray], 16/07/1891. BM

v.c. 5 West Sedgemoor, in ditch both sides of Swell Drove, ST356247, Wild Flower Society, 12/06/2011.

v.c. 5 West Sedgemoor, common in ditches, ST3424, ST3625, ST3726, S.J. Parker \& Natural England staff, 07/2016.

v.c. 5 North Moor, drove side rhyne, ST32123109 and drove side rhyne and field ditch, ST32753130, Somerset Rare Plants Group, 23/07/2011.

v.c. 5 Muchelney, ST4225, S.J. Parker, 17/08/2016.

v.c. 6 Knowle, ST3339, I.P. Green, 09/09/2003. (Det. H.J.C. \& F.J.R., 2016).

v.c. 6 Knowle, scattered along SW side of King's Sedgemoor Drain, ST33083993, ST33273980, ST33283979, ST33303978, ST33313977, H.J.C. \& F.J.R., 02/12/2016.

v.c. 6 Huntspill Moor, in ditch at junction of two rhynes, by water level structure, ST35984333, E.J. McDonnell, 23/08/2016.

v.c. 6 Gold Corner, S bank of the Huntspill River by Gold Corner bridge, ST36904304, E.J. McDonnell, 17/08/2016.

v.c. 6 Southlake Moor, in field ditch W of Short Drove, ST36973061, BSBI, 05/06/2011.

v.c. 6 Southlake Moor, ditch alongside Burrow Hill Drove, ST36113043, ST36723055, H.J.C. \& Wiltshire Botanical Society, 06/07/2014.

v.c. 6 Moorlinch, ST3836, S.J. Parker, 19/07/2018.

v.c. 6 Chilton Moor, in N-S ditch at W. edge of Unit 138 of SSSI, ST37554179, H.J.C., 11/09/2013.

v.c. 6 Chilton Moor, in N-S ditch of Unit 140 of SSSI, nr S. edge of moor, ST38154123, H.J.C., 03/09/2013.

v.c. 6 Catcott, Edington and Chilton CC103, ditch, ST414436, R.M. Walls 533, 27/06/1996. Herb RMW

v.c. 6 Catcott Lows, large patch in SW corner of N field, ST40124185, H.J.C. \& S.J. Parker, $11 / 08 / 2015$.

v.c. 6 Catcott Grounds, in E-W ditch at E edge of SSSI Unit 157, ST41484364, H.J.C., 23/08/2013.

v.c. 6 Shapwick Moor, ditch along S edge of Fen Field, N and W of Black Ditch/Mill Brook, ST4040, A. Robinson \& Somerset Botany Group (det. H.J.C.), $18 / 09 / 2018$.

v.c. 6 King's Sedgemoor, below Walton windmill, in partially dried up ditches, very abundant [ST43], V.S. Summerhayes, 11/08/1943. K

v.c. 6 King's Sedgemoor, ST4032, G. Keele \& Somerset Botany Group (det. H.J.C.), 20/09/2016.

v.c. 6 Butleigh Moor, N. side of Fisher's Drove, ST455345, S.J. Parker, 25/07/2011.

v.c. 6 Walton Moor, ditch on S side of drove leading to decoy pool, ST45633385, H.J.C., 31/08/2011.

v.c. 6 Walton Moor, ditch on E side of lane, just south of drove, ST45753475, H.J.C., 31/08/2011.

v.c. 6 Street Moor, much in rhyne, ST46923347, J. Poingdestre, 11/10/2015.

v.c. 6 Marshes near Glastonbury, J.M. Day, 12/08/1948. K

v.c. 6 Meare, N of, ST450424, H. Gibbons, 2009 (Det. H.J.C. \& F.J.R., 2018). 
v.c. 6 Meare, N of, in ditches, ST45024255, ST45114233, ST45134235, ST45144266, H.J.C. \& F.J.R., 07/09/2018.

v.c. 6 Godney, in ditch W side of road, S of Godney Farm, ST486421, H.J.C., 18/05/2009 (Det. H.J.C. \& F.J.R., 2018).

v.c. 6 Godney, in ditch W side of road, S of Godney Farm, ST48594233, ST48614227, H.J.C. \& F.J.R., 07/09/2018.

v.c. 6 Kennard Moor, in ditch on N side of road, ST52253640, ST52303630, H.J.C. \& F.J.R., 23/10/2018.

v.c. 9 Stour, [?] Bryanstone, J.C. Mansel, Sept. 1863. DOR

v.c. 9 Marnhull, R. Cale just downstream of Cale Bridge, ST759199, A.P. Branson, 22/09/2011.

v.c. 9 Marnhull, NE of, 4 patches on E side of River Cale, upstream of Cale Bridge, ST75932053, ST75912049, ST75942045, ST75962038, H.J.C \& F.J.R., $19 / 08 / 2016$.

?v.c. 9 " not labelled at time, No doubt Dorset (probably) Sturminster Newton, where abundant in R. Stour", E.F. Linton, Aug. 1891. BM

v.c. 17 Roadside pond, Iville farm, near Baynards, [TQ0634] A.H. Wolley-Dod, 21/07/1920. BM

v.c. 17 Shalford Common, pond NE corner of the common, J.G. Lawn, 08/1931.

v.c. 17 Shalford Common, by pond, E.C. Wallace, 11/08/1934. BM, K, RNG

v.c. 17 Shalford, Rice's Corner, pond behind farm, E of farmyard \& W of Great Tangley Manor, J.C. Gardiner, 27/07/1958. BM (det. F.J.R.)

v.c. 17 Thorpe Park, Fleet Lake, very small stand in bay, TQ035687, R.V.L \& N. Monaco, 18/08/2010.

v.c. 17 Thorpe Park, Manor Lake, large stand along ditch \& spreading out into lake margin, TQ027685, R.V.L \& N. Monaco, 19/08/2010.

v.c. 17 Thorpe Park, Manor Lake, small narrow band along lake margin, TQ030686, R.V.L \& N. Monaco, 19/08/2010.

v.c. 17 Thorpe Park, Abbey Lake, very large stand approx. 80m long along margin, TQ038680, R.V.L \& N. Monaco, 19/08/2010.

V.c. 17 Thorpe Park, Abbey Lake, large stand along E shore, TQ038678, D.A. Broughton, 21/07/2015.

v.c. 18 Shenfield Common pond, TQ60019345, M. Smith, 22/09/2003 (det. M.P. Wilcox, 2012). BM

v.c. 18 Codham Hall Farm near Cranham, in remains of pond, TQ58628884, M. Smith, 27/07/2006 (det. M.P. Wilcox, 2012).

v.c. 18 Langdon Hills Golf \& Country Club, lots with B. maritimus in at least 2 ponds and another nearby, ST66048596, M. Smith, 06/07/2018.

v.c. 18 Billericay, Gloucester Park, on edge of fishing lake, planted, TQ69828908, Essex Botanical Society (det. K. Adams), 14/08/2018.

v.c. 18 Billericay, Gloucester Park, small clump on corner of lake, TQ69828910, K. Adams \& E. Barrie, 07/09/2018.

v.c. 20 Bovingdon, pond near Green, half mile from Bovingdon, [TLO0B] E.B. Bangerter \& J.G. Dony 755, 29/07/1959. BM

v.c. 21 margin of the lake, grounds of Buckingham Palace, J.E. Lousley, 04/09/1956. $\mathbf{B M}, \mathbf{K}$

v.c. 21 S.W. corner of Paradise fields, Greenford, Ealing, I.J. Kitching, 12/07/2003. BM

v.c. 21 Northwick Park, Brent, TQ169872, L. Williams, 06/09/2007. BM 
v.C. 21 Northwick Park, Brent, TQ169872, L. Williams, 17/08/2011. BM

v.c. 21 Brent Reservoir, Brent, TQ213870, L. Williams, 17/08/2011. BM

v.c. 22 Frogmore near Windsor on side of lake in Home Park, C.E. Hubbard, 09/1928. K

v.c. 22 Theale, Englefield Park, by the lake, [SU6271] E.V. Watson, 16/10/1955.

\section{RNG}

V.C. 31 Washingley farm pond W of Manor Farm, TL13698845, P. Stroh, 30/06/2015.

v.c. 37 Holt Castle, by pool on edge of Severn flood plain, SO831625, R. Maskew (det. R. Maskew \& F.J.R.), 20/08/2011. BM

v.c. 40 Preston Montford, pond in grounds of Field Study Centre, SJ433143, P.C. Hall, 14/07/1961. BM

v.C. 40 Preston Montford, pond margin, SJ43451443, F.J.R., 14/04/2012. BM (Fruit only)

v.c. 40 Oss Mere, SJ5643, F.M. McCullagh \& H. Griffiths (det. S.J. Whild), 9/07/2007.

v.c. 40 Oss Mere, SJ565438, M. Cousins (det. F.J.R.), 17/09/2013.

v.c. 55 Melton Country Park, SK757205, A. Semper, 20/09/2015.

v.c. 55 Melton Country Park, large population on lake edge, possibly introduced, SK75772053, SK75852051, S. Mathers (det. D. Simpson), 09/09/2016.

v.c. 55 North Kilworth, Kilworth Springs Golf Club, at edge of lake on golf course, SP613823, and at edge of small lake on golf course, SP614818, both probably introduced, G. Hall, 28/09/2017.

v.c. 56 a dyke which was at one time the river [..] of the Trent, Girton, Notts. [SK86], R.C.L. Howitt, April 1951. K

v.c. 58 Marbury Mere, nr Whitchurch, SJ561455, G. Kay (det. M.P. Wilcox), 09/2011.

v.c. 62 Eastfield Farm, $\mathrm{N}$ of Great Ayton, introduced but naturally regenerating in a few places round the pool, NZ554132, V. Jones (det. M.P. Wilcox), 26/08/2013.

v.c. 64 Burley-in-Wharfedale, top field in reed bed, SE1546, M. Atkinson (det. D.A. Broughton), 2001.

v.c. 64 Ilkley, Ben Rhydding Gravel Pits, near Carex rostrata, second clump at opposite (W) end under flowering currant, SE1447, F.C. Draper, 2008 (known here since 1986).

v.c. 64 Ilkley, Ben Rhydding Gravel Pits, stands around S end of S pit, SE145476, D. Broughton, 08/05/2011.

Copyright retained by author(s). Published by BSBI under the terms of the Creative Commons Attribution 4.0 International Public License.

ISSN: $2632-4970$

https://doi.org/10.33928/bib.2019.01.091 